\title{
PHYTOTOXICITY AND COMPETITIVE EFFECT OF SOME WEEDS ON ONION CROP AND ITS CONTROL METHODS. Hamza, Amany M. ${ }^{1}$ and I. E. Soliman ${ }^{2}$ \\ 1 Pesticides Dept., Fac. Agric., Kafr-El-sheikh University, 33516 Egypt. 2 Weed Res. Laboratory, Field Crops Res. Inst., Agric. Res. Center, Giza, Egypt
}

\begin{abstract}
This study was carried out during 2008/2009 and 2009/2010 seasons to evaluate the phytotoxicity and competitive effect of some weed species (Ammi majus L.), ( Rumex dentatus, L.), (Chenopodium album L.), (Convolvulus arvensis, L.) and (Melilotus indicus, Ten.) on seed germination, seedling vigour, growth characters and yield of onion. Moreover, to evaluate the efficiency of different control methods (chemical and hand hoeing) against onion weeds. The results showed that, (seeds + roots) exudates of the different tested weeds caused a significant decrease in seeds germination and seedling vigour characters of onion, i.e., seedling length, shoot length, root length and seedling fresh weight. On the other hand results of the competitive effect of weed species on growth characters and yield of onion, showed that, the growing tested weeds with onion decreased significantly onion growth characters, i.e plant height, number of leaves/plant, bulb and neck diameter and dry weight/plant compared to control treatment (onion grown alone). The competitive ability of (Ammi majus) was more pronounced than the other tested weeds on the growth of onion as well as the average bulb weight at harvest.

Also, results indicated that all herbicidal treatments showed significant efficacy against total weed during both seasons. The most effective treatment against total weeds was hand hoeing twice, followed by pendimethalin, oxadiargyl and Metribuzin + fluazifop-P-butyl, respectively. All tested herbicidal treatments significantly increased onion growth characters during the growing stage and at harvest during both seasons. Bulb onion yield/fed significantly increased to different extents as result of using the tested herbicidal treatments in both seasons as compared to control.

Generally, it is concluded that the interference (phytotoxicity and competition) of weeds with onion caused an evident harm in the seed germination, growth and yield of onion especially (Ammi majus) and (Melilotus indicus). So, weed elimination in transplanted onion by these potent herbicides can be recommended for weed control in transplanted onion.
\end{abstract}

Keywords: seed; germination; efficiency; herbicides, weeds, onion.

\section{INTRODUCTION}

Onion (Allium cepa L.) belonging to the family Alliaceae is one of the important vegetable and field crops with world production of about 55 million tones (FAO, 2004). It is a condiment crop consumed as fresh in salads and as a spice in cooking dishes. One of the causes of this low production is the high levels of weeds, reflecting inadequate control measures. Dryden and Karishnamurthy (1974) reported from India that weeds could take about 30$40 \%$ plant nutrients applied to the crop. The poor competitive ability of onion has been attributed to its initial slow growth and lack of adequate foliage to smother weeds (Wicks et al., 1973). Reduction in bulb yield by $36-48 \%$ has 
been reported from Sudan due to unrestricted weed growth in onion (Babiker and Ahmed, 1986) whereas losses from $49 \%$ to $86 \%$ and up to $96 \%$ have been reported from India and UK, respectively, from weed interference (Bond and Burston, 1996).

Onion (Allium cepa L.) cannot tolerate prolonged competition from weeds because of its initial slow growth rate after planting, shallow fibrous roots, and small above-ground canopy for effective soil shading (Carlson \& Kirby 2005). Direct-seeded onion is clearly more sensitive to weed competition than bulbs or seedlings (Gaskell et al. 1998; Corgan et al. 2000). Of the 27 crop species tested in one study, onion ranked the least competitive against weeds (Karim et al. 1998). Weedy plots resulted in the lowest marketable onion yield (Vanhala 1999). A strong negative correlation was found between the yield and the weed infestation period, while the relative yield was more sensitive to the duration of weed competition rather than to the weed load. To prevent yield loss, onion plants need to remain weed-free for 8 weeks after emergence, as a delay in weed removal during this period halved the final yield (Gazdag-Torma 1997). The bulb size class distribution and average onion price were both affected by weed competition (Dunan et al. 1996). Weed competition in salad onion plots from sowing until harvest, when sown at different times of the year, caused a reduction in the fresh weight yield by $96 \%$ compared to that obtained from the weed-free controls.

Moreover, allelopathic effects of weeds against onion considered a source of major concern. For example, (Chenopodium album) is an odorless, branching, largely annual weed diffused in cultivated fields (Holm et al., 1977), commonly known as lambsquarters. Mallik et al. (1994) reported the presence of growth inhibitory substances in this plant. They evidenced the aqueous extract inhibited the germination and growth of radish and wheat seeds, attributing the activity to the presence of phenols.

Weed management for onion has included monitoring, cultural practises, mechanical and biological methods, and the use of herbicides (Masiunas 2002). Several herbicides used as early post-emergence treatments for annual weed control in onions must be applied only at certain stages of growth to avoid injury to the crop (Ashton and Monaco, 1991). Herbicides may be applied before planting or after planting. Pre-planting application of soil residual herbicides, such as, oxadiazon and trifluralin proved equally effective for weed control (Amrutkar et al., 2002). Oxyfluorfen, pendimethalin and metribuzin significantly reduced the weed population and increased onion yield to levels at 53 days after sowing and repeated at 80 days gave excellent weed control (Noll, 1978). A combination of pendimethalin with one hand weeding resulted in the greatest weight and maximum number of onion seedlings and minimum fresh weight of weeds (Pandey et al., 1991). The use of selective herbicides together with mechanical methods for weed control in onion has been recommended (Rapparini, 1994). Ghaffoor (2004) reported that pendimethalin at 0.99 I a.i. $\mathrm{ha}^{-1}$ controlled weeds effectively and gave the highest bulb yield.

Therefore, the objectives of this study were, to study the allelopathic and competitive effects of some common weeds (Ammi majus L.), (Rumex 
dentatus, L).,(Chenopodium album L)., (Convolvulus arvensis, L.) and (Melilotus indicus, Ten) on seeds germination, seedling vigor, growth and yield of onion (Allium cepa, L.) and to evaluate the efficacy of different herbicides as well as hand weeding in controlling onion weeds.

\section{MATERIALS AND METHODS}

\section{Phytotoxic effect of some weed extracts on onion crop plant:}

This experiment was carried out at the Weed Research Laboratory, Sakha Experimental Station, Kafr El-Sheikh during 2008/2009 and 2009/2010 seasons to study the phytoxic effect of the (seeds + roots) exudates of some onion weed species (Ammi majus L.), (Chenopodium album, L.), (Convolvulus arvensis, L.) (Melilotus indicus, Ten.) and (Rumex dentatus, L.) on the seeds germination and seedling vigour of onion plant. The experiment included six treatments; five treatments of (seeds + roots) exudates of the five weed species and one control treatment. Treatments were arranged in a completely randomized design with four replications. Eight hundred seeds of each tested weed were germinated in four Petri-dishes (every dish contains 200 seeds) using distilled water under laboratory conditions at $20^{\circ} \mathrm{C}$. After two weeks, (seeds + roots) exudates of each weed species were collected and diluted in $400 \mathrm{~mL}$. distilled water according to the method described by Moursi et al., (1983).

Ten of onion seeds El-Bhary cv. were cultivated at the last week of November in plastic pots (20 cm diameter and $25 \mathrm{~cm}$ depth), filled with clean sand. Adequate quantity $(20 \mathrm{ml})$ of (seeds + roots) exudates was added daily to each pot during the experimental period. The control treatment was irrigated with the same quantity of distilled water. After 15 days from sowing the germination percentage of onion seeds was calculated, and seedling length, shoot length, root length and seedling fresh weight were estimated.

\section{The competitive effect of weeds on growth and yield of onion:}

This experiment was carried out in plastic pots to study the competitive effect of the five selected weed species on the growth and yield of onion during the tested two seasons. The experiment included six treatments [5 interpolating treatments (onion +5 weed species) as well as control treatment (onion alone]. The treatments were arranged in a completely randomized design with eight replications.

Seeds of onion (El-Bhary cv.) and weeds were cultivated at the last week of November in the two seasons in plastic pots $(20 \mathrm{~cm}$ diameter and 25 $\mathrm{cm}$ depth) filled with 2:1 mixture of silty clay loam and sand. All pots were watered as needed by alternate sub-irrigation. After two weeks, the plants in every pot were thinned to five plants of onion + five plants of weed in the inter-planting treatments and to five plants of onion only in the control treatment. At 120 days after sowing, from four replications, onion plants in each pot were taken to determine the following growth characters (plant height, number of leaves/plant, bulb and neck diameter, bulbing ratio and total plant dry weight). Also, the weed plants in each pot were taken to 
determine the dry weight/plant. At harvest, from the other four replications, the onion plants in each pot were taken to record the average bulb weight.

The efficacy of some herbicides and hand hoeing against the onion weeds:

This experiment was conducted at Sakha Agricultural Research Station during the two seasons to evaluate the efficacy of some herbicides for controlling weeds in onion (Allium cepa, L.). The first treatment was Stomp (Pendimethalin $50 \% \mathrm{EC}$ ), at the rate of $1.7 \mathrm{l} / \mathrm{fed}$, applied as pre-transplanting. The second treatment was Topstar (oxadiargyl $80 \% \mathrm{WG}$ ), at the rate of 0.2 $\mathrm{g} / \mathrm{fed}$, applied 7 days after transplanting. The third treatment was Sencor (Metribuzin 70\% WP), at the rate of $0.07 \mathrm{l} / \mathrm{fed}$,, applied pre-transplanting + fusillade super (fluazifop-P-butyl $12.5 \% \mathrm{EC}$ ), at the rate of $0.5 \mathrm{l} / \mathrm{fed}$, applied 30 days after transplanting. The forth treatment was Hand hoeing (twice) at 30 and 45 days after transplanting. The last treatment was the control (untreated). This experiment was carried out on a silty clay soil that has a $\mathrm{pH}$ of 7.8 and an organic matter content of $1.0 \%$. Herbicides in both field experiments were sprayed by Knapsack sprayer $\mathrm{CP}_{3}$ with water volume of $200 \mathrm{l} / \mathrm{fed}$, in both seasons. Fertilizers such as calcium super phosphate $\left(15.5 \% \mathrm{P}_{2} \mathrm{O}_{5}\right)$ at the rate of $100 \mathrm{~kg} / \mathrm{fed},{ }^{1}$, was added before transplanting and ammonium nitrate $(33.5 \% \mathrm{~N})$ at the rater of $238 \mathrm{~kg} / \mathrm{fed}$, was added before the $1^{\text {st }}$ and $2^{\text {nd }}$ irrigation. Each experiment was carried out in a randomized complete block design with four replicates. The plot area was $3.5 \times 3 \mathrm{~m}^{2}$. Seedlings of onion cultivar El-Bhary, were transplanted at the last week of November in the two seasons, where onion seedlings were transplanted in two sides on each ridge in $10 \mathrm{~cm}$ apart. All agronomic practices in onion such as land preparation, fertilization and irrigation were done as recommended during the two seasons of study. The collected data were as follows:

On weeds:

Weeds were hand pulled at random from one square meter from each plot after 60 days from transplanting and classified into three categories (broad-leaved, grassy and total weeds), the fresh weight of each species was estimated as $\left(\mathrm{g} / \mathrm{m}^{2}\right)$.

\section{Onion growth characters and yield components:}

Samples of 10 onion plants were collected at random from each plot after 90 days from transplanting and at harvest to estimate onion growth characters, i.e. plant height $(\mathrm{cm})$, fresh weight of leaves/plant and fresh weight of bulb $(\mathrm{g})$. While yield and its components (fresh weight of marketable and non-marketable bulb yield $/ \mathrm{m}^{2}$ and average fresh weight of marketable and non-marketable bulb $(\mathrm{g})$ were determined at harvest from each plot.

\section{Statistical analysis:}

The obtained data were subjected to proper statistical analysis of variance according to Snedecor and Cochran (1980). Treatment mens were compared using Duncan's multiple range test (Duncan, 1955) at the $5 \%$ level of propability. 


\section{RESULTS AND DISCUSSION}

\section{Effect of tested weeds exudates on onion germination and seedling characters:}

The effect of (seeds + roots) exudates of the five tested weeds (Ammi majus L.), (Chenopodium album, L.), (Convolvulus arvensis, L).( Melilotus indicus, Ten.) and (Rumex dentatus, L.) as an indicator to their allelopathic effect on onion seed germination and seedling development is presented in Table 1. The data showed that the use of (seeds + roots) exudates of the different tested weeds caused a significant decrease in the germination percentage, seedling length, shoot length, root length and seedling fresh weight of onion compared to the control treatment (distilled water). (Seed + root) exudates of (Melilotus indicus) were more effective in decreasing seed germination percentage and shoot length than the other weeds. The inhibitory effect of the (seeds + roots) exudates of this weed on seeds germination percentage and shoot length was 19.34 and $36.07 \%$, respectively. However, seedling length, root length and seedling fresh weight were found to be more sensitive to (seeds + roots) exudates of (Ammi majus) compared to the other weeds. The reductions in seedling length, root length and seedling fresh weight of onion germinated in (seeds + roots) exudates of (Ammi majus) were $31.02,27.33$ and $28.49 \%$, respectively compared to the control treatment. On the other hand, the lowest inhibition in the traits studied was obtained by using of (seeds + roots) exudates of (Rumex dentatus). The inhibitory effect of (seeds + roots) exudates of the tested weeds on germination percentage and seedling development of onion may be due to some compounds released from weed seeds and roots into the environment which affect certain physiological process especially cell division and elongation. In this respect, Corchoranl et al. (1972) demonstrated that many chemicals, i.e., tannins, coumarin, cinnamic acid and phenolic compounds inhibited gibberellin induced growth in pea seedling. Moreover, other investigators reported the importance of phenolic acids as allelopathic compounds, where it inhibited the mineral uptake by plant roots (Glass, 1974), photochemical reaction of photosynthesis (Rice, 1974), and stimulated the respiration in plant (Dedonder and Van Sumere, 1971).

Table 1: Effect of (Seed + Root) exudates of different tested weeds on onion germination and seedling development.

\begin{tabular}{|l|c|c|c|c|c|c|c|c|c|c|}
\hline \multirow{2}{*}{ Treatments } & \multicolumn{2}{|c|}{ Germination } & \multicolumn{2}{c|}{ Seedling length } & \multicolumn{2}{c|}{ Shoot length } & \multicolumn{2}{c|}{ Root length } & \multicolumn{2}{c|}{$\begin{array}{c}\text { Seedling fresh } \\
\text { weight }\end{array}$} \\
\cline { 2 - 12 } & $\%$ & $\% \mathbf{R}^{\star}$ & $\mathbf{c m}$ & $\% \mathbf{R}^{\star}$ & $\mathbf{c m}$ & $\% \mathbf{R}^{\star}$ & $\mathbf{c m}$ & $\% \mathbf{R}^{\star}$ & $\mathbf{g m}$ & $\% \mathbf{R}^{\boldsymbol{*}}$ \\
\hline A.majus & $72.75 \mathrm{~d}$ & 24.22 & $11.23 \mathrm{~d}$ & 31.02 & $4.98 \mathrm{~d}$ & 35.16 & $6.25 \mathrm{~d}$ & 27.33 & $35.41 \mathrm{~d}$ & 28.49 \\
C. album & $83.40 \mathrm{c}$ & 13.13 & $14.74 \mathrm{~b}$ & 9.46 & $7.00 \mathrm{~b}$ & 8.85 & $7.74 \mathrm{bc}$ & 10.63 & $43.85 \mathrm{~b}$ & 11.45 \\
C.anvensis & $86.21 \mathrm{~b}$ & 10.21 & $14.00 \mathrm{c}$ & 14.00 & $6.21 \mathrm{c}$ & 19.14 & $7.79 \mathrm{~b}$ & 9.42 & $42.56 \mathrm{bc}$ & 14.05 \\
M. indicus & $77.43 \mathrm{~d}$ & 19.34 & $11.42 \mathrm{~d}$ & 29.85 & $4.91 \mathrm{~d}$ & 36.07 & $6.51 \mathrm{~d}$ & 24.30 & $37.24 \mathrm{~d}$ & 24.80 \\
R. dentatu & $87.52 \mathrm{~b}$ & 8.83 & $14.15 \mathrm{bc}$ & 13.08 & $6.70 \mathrm{c}$ & 12.76 & $7.45 \mathrm{c}$ & 13.37 & $40.73 \mathrm{c}$ & 17.75 \\
\hline Control & $96.00 \mathrm{a}$ & & $16.28 \mathrm{a}$ & & $7.68 \mathrm{a}$ & & $8.60 \mathrm{a}$ & & $49.52 \mathrm{a}$ & \\
\hline
\end{tabular}

Values followed by the same letter were not statistically different at $5 \%$ level of significance according to Duncan's multiple range test.

* $\% \mathbf{R}=\%$ of Reduction $\%=(\mathrm{C}-\mathrm{T}) / \mathbf{C} \times 100$ 
El-Habbasha and Behairy (1977) found that root exudates of squash, cabbage and bean depressed the germination of onion seeds, fresh and dry weight of onion seedlings. Also, these results are in harmony with those obtained by Singh et al., (2006).

\section{Effect of weeds competition on onion growth}

Data in Table 2 showed that, the growing weeds with onion caused a significant reduction in the growth characters of onion plants, i.e. plant height, number of leaves/plant, bulb, neck diameter and dry weight/plant. Moreover, it could be noticed that the competitive ability of (Ammi majus) was more pronounced than the other tested weeds on the growth of onion plant. Thereby, growing (Ammi majus) with onion plant caused a high reduction in plant height ( 39.35 and 38.18 ), number of leaves/plant ( 4.38 and 4.59 ), bulb diameter (2.59 and 2.43 ), neck diameter (1.03 and 1.04 ) and dry weight/plant (3.04 and 3.29 ) compared to onion grown alone in both tested seasons, respectively.

The results in Table 2 also showed that, the growing weed species with onion decreased onion bulb weight at harvest compared to control (onion alone), particularly (Ammi majus) and (Melilotus indicus) which caused highest losses in the bulb weight $(13.93,13.54 \%$ and $14.58,13.37 \%$ ) in both seasons, respectively. This means that the competitive abilities of these two weed species on onion plants were higher than that of the other tested weeds. The highest competitive abilities of (Ammi majus) and (Melilotus indicus) may be due to the increase in their dry weight per plant than the other tested weeds as shown in Table 2. On the other hand, growing (Convolvulus arvensis) and (Remx dentatus) with onion caused less reduction in onion yield. In this respect, Abd El-Aal and El-Haroun (1989) found that, the competition of weeds with onion plants decreased significantly the onion yield. Angira et al. (1988) indicated that aqueous extracts delayed the germination and decreased the root and shoot lengths and number of leaves in chickpea.

Weeds compete with the onion plants for water, light, and nutrients, thus adding considerably to the cost of production. The onion crop is seriously impaired by weed competition and under heavy infestation, the yield loss may be as high as $100 \%$ (Qasem 2005). However, under the Jordan Valley conditions, competition for water and nutrients is more severe than for the other growth prerequisites, such as light. The results of the present study showed that weed competition is strong and can be the cause of a serious deterioration of crop yield and quality (bulb size), resulting in a low marketable yield. Under low or poor soil fertility conditions and for commercial and economic crop production, crop requirements, such as fertilizer and water, become limiting and critical. However, the positive impact of the application of these essential requirements only enhanced weed growth. It is well-established that competition mainly occurs when one or more of the requirements of growth (e.g. water, light, and nutrients) are in limited supply (Qasem 1987). Therefore, the farmers have tried to compensate for weed competition in the crop plants by increasing the supply of fertilizer. Weed competition significantly reduced the onion bulb yield when the crop was established from the three types of planting material and the weeds were allowed to compete longer than 35 days after planting. However, the highest 
survival, growth, and yield were obtained when the bulbs were used as planting material. Bulbs produce shoots more rapidly than seeds and the plants that are produced are stronger and establish earlier than those grown from the other two types of planting material (Gaskell et al. 1998), thus nullifying the weed competition effects. This is related to the availability of the stored food in the bulbs, sufficient to support the onion plants for their initial growth period. It has been reported that small plants from seeds sustain a greater loss than larger ones raised from seedlings or bulbs (Corgan et al. 2000). In the present work, it was observed that the plants grown from bulbs are vigorous and form the above-ground canopy shortly after planting. In contrast, the plants grown from seeds were weak, sensitive to weed competition and shading, and were not able to tolerate weed competition for a long period after emergence. Singh et al. (1989) studied allelopathic effect as aqueous extracts of (Imperata cylindrical), (Ageratus conyzoide)s and (Commelina benghalensis) on germination and vigour of soybean and maize. Allelopathic interactions in traditional agroforestry systems gained prominent attention of scientists involved in allelopathy research (Todaria et al., 2005). The volatile allelochemicals released from many other plant species can affect the growth and productivity of plants in the vicinity (Singh et al., 2006).

Finally, it could be concluded that the interference between the weeds and onion plants caused an evident harm in the seed germination, seedling vigour, growth characters and onion yield especially the weeds (Ammi majus) and (Melilotus indicus). Therefore, the interference of weeds with crop deserves increased attention, not only to inter-specific competition between weeds and crops for water, minerals and light, but also to their allelopathic effects.

Table 2: Competitive effect of different weeds on growth characters and yield of onion plant during the two growing seasons.

\begin{tabular}{|c|c|c|c|c|c|c|c|c|}
\hline \multirow[b]{3}{*}{ Treatments } & \multicolumn{6}{|c|}{ Growth characters at 120 days after sowing } & \multicolumn{2}{|c|}{$\begin{array}{c}\text { Onion yield at } \\
\text { harvest }\end{array}$} \\
\hline & \multicolumn{5}{|c|}{ Onion plants } & \multirow[b]{2}{*}{$\begin{array}{c}\text { Weeds } \\
\text { Dry } \\
\text { weight } \\
\text { plant }^{-1} \\
\text { (gm) }\end{array}$} & \multirow{2}{*}{$\begin{array}{c}\text { Average } \\
\text { bulb } \\
\text { weight } \\
\text { (gm) }\end{array}$} & \multirow[b]{2}{*}{$\begin{array}{c}\text { Reduction } \\
\%\end{array}$} \\
\hline & $\begin{array}{c}\text { Plant } \\
\text { height } \\
(\mathrm{cm})\end{array}$ & $\begin{array}{l}\text { No. of } \\
\text { leaves } \\
\text { /plant }\end{array}$ & $\begin{array}{c}\text { Bulb } \\
\text { diameter } \\
(\mathrm{cm})\end{array}$ & $\begin{array}{c}\text { Neck } \\
\text { diameter } \\
(\mathrm{cm})\end{array}$ & $\begin{array}{c}\text { Dry } \\
\text { weight } \\
\text { plant } \\
\text { (gm) }\end{array}$ & & & \\
\hline \multicolumn{9}{|c|}{ First season } \\
\hline Onion + A. majus & $39.35 \mathrm{c}$ & $4.38 \mathrm{c}$ & $2.59 \mathrm{~b}$ & $1.03 c$ & $3.04 \mathrm{~d}$ & $1.48 \mathrm{ab}$ & $13.93 d$ & 50.71 \\
\hline Onion + C. album & $43.12 b$ & $5.07 b$ & $2.83 b$ & $1.20 \mathrm{~b}$ & $3.69 \mathrm{c}$ & $1.43 b$ & $15.22 \mathrm{bc}$ & 46.14 \\
\hline Onion + C. arvensis & $43.83 \mathrm{~b}$ & $5.24 b$ & $2.89 b$ & $1.11 \mathrm{c}$ & $3.98 b$ & $1.31 \mathrm{c}$ & $19.36 b$ & 31.49 \\
\hline Onion $+M$. indicus & $40.69 \mathrm{c}$ & $5.00 \mathrm{~b}$ & $2.92 b$ & $1.09 c$ & $3.21 \mathrm{~d}$ & $1.65 \mathrm{a}$ & $14.58 \mathrm{c}$ & 48.41 \\
\hline Onion $+R$. dentatus & $42.54 \mathrm{~b}$ & $5.65 b$ & $2.80 \mathrm{~b}$ & $1.23 b$ & $4.09 \mathrm{~b}$ & $0.37 d$ & $19.52 b$ & 30.92 \\
\hline Control (Onion only) & $52.35 \mathrm{a}$ & $6.68 \mathrm{a}$ & $3.67 \mathrm{a}$ & $1.36 \mathrm{a}$ & $5.63 \mathrm{a}$ & & $28.26 \mathrm{a}$ & \\
\hline \multicolumn{9}{|c|}{ Second season } \\
\hline Onion + A. majus & $38.18 c$ & $4.59 c$ & $2.43 \mathrm{~b}$ & $1.04 \mathrm{c}$ & $3.29 \mathrm{~d}$ & $1.41 \mathrm{ab}$ & $13.54 \mathrm{~d}$ & 47.94 \\
\hline Onion + C. album & $39.03 \mathrm{~b}$ & $5.13 b$ & $2.65 b$ & $1.14 b$ & $3.65 c$ & $1.35 b$ & $16.32 c$ & 37.25 \\
\hline Onion + C. arvensis & $41.32 b$ & $5.00 \mathrm{~b}$ & $2.73 b$ & $1.10 \mathrm{~b}$ & $4.20 \mathrm{~b}$ & $1.12 \mathrm{c}$ & $17.25 b$ & 33.68 \\
\hline Onion $+M$. indicus & $40.37 b$ & $5.27 b$ & $2.26 \mathrm{~b}$ & $1.07 c$ & $3.42 \mathrm{~d}$ & $1.45 \mathrm{a}$ & $13.37 \mathrm{e}$ & 48.60 \\
\hline Onion $+R$. dentatus & $39.01 \mathrm{~b}$ & $5.41 \mathrm{~b}$ & $2.54 \mathrm{~b}$ & $1.16 \mathrm{~b}$ & $4.31 \mathrm{~b}$ & $0.38 d$ & $17.48 \mathrm{bc}$ & 31.41 \\
\hline Control (Onion only) & $50.96 \mathrm{a}$ & $6.42 \mathrm{a}$ & $3.52 \mathrm{a}$ & $1.43 a$ & $5.91 \mathrm{a}$ & & $26.01 \mathrm{a}$ & \\
\hline
\end{tabular}
significance according to Duncan's multiple range test. 
Effect of weed control treatments on fresh weight of weeds:

Data in Table (3) showed that, in control plots, the annual yield of broad-leaved weeds were about 94.8 and $5.2 \%$ of the total annual weeds yield compared with 93.5 and $6.5 \%$ for annual grassy weeds in the first and second seasons, respectively. Results indicated that all herbicidal treatments as well as hand hoeing significantly decreased the fresh weight of total weeds in both tested seasons as compared with the control treatment. These results are in a complete harmony with those mentioned by Sanjeev et al. (2003) and Ghalwash et al. (2008), they indicated that oxyfluorfen, pendimethalin and Metribuzin significantly reduced the weed population.

Table 3: Effect of weed control treatments on fresh weight $\left(\mathrm{g} / \mathrm{m}^{2}\right)$ of annual weeds in onion after $\mathbf{7 0}$ days of transplanting during the two sowing seasons.

\begin{tabular}{|c|c|c|c|c|c|c|c|}
\hline \multirow[b]{2}{*}{ Treatments } & \multirow[b]{2}{*}{$\begin{array}{c}\text { Rate/ } \\
\text { fed } \\
\text { (g or I) }\end{array}$} & \multicolumn{3}{|c|}{ First season } & \multicolumn{3}{|c|}{ Second season } \\
\hline & & $\begin{array}{l}\text { Broad } \\
\text { leaved } \\
\text { weeds } \\
\left(\mathrm{g} \mathrm{m}^{-2}\right)\end{array}$ & $\begin{array}{l}\text { Grassy } \\
\text { weeds } \\
\left(\mathrm{g} \mathrm{m}^{-2}\right)\end{array}$ & $\begin{array}{c}\text { Total } \\
\text { weeds }(g \\
\left.\mathrm{m}^{-2}\right)\end{array}$ & $\begin{array}{c}\text { Broad } \\
\text { leaved } \\
\text { weeds }(g \\
\left.\mathrm{m}^{-2}\right)\end{array}$ & $\begin{array}{l}\text { Grassy } \\
\text { weeds } \\
\left(\mathrm{g} \mathrm{m}^{-2}\right)\end{array}$ & $\begin{array}{c}\text { Total } \\
\text { weeds } \\
\left(\mathrm{gm}^{-2}\right)\end{array}$ \\
\hline Pendimethalin & 1.7 & 229.0 & 15.2 & 244.2 & 219.3 & 18.2 & 237.5 \\
\hline Oxadiargyl & & 295.6 & 18.8 & 314.4 & 236.6 & 19.7 & 256.3 \\
\hline $\mathrm{M}+\mathrm{F}^{\star}$ & $0.07+0.5$ & 314.2 & 12.6 & 326.8 & 252.4 & 14.6 & 267 \\
\hline Hand hoeing & Twice & 196.8 & 16.4 & 213.2 & 190.85 & 20.0 & 210.85 \\
\hline Control & & 5464.0 & 297 & 5761 & 4092.0 & 286.2 & 4378.2 \\
\hline LSD at $5 \%$ & & 356.0 & 85.2 & 361.0 & 197.3 & 47.2 & 214.0 \\
\hline
\end{tabular}

${ }^{*} \mathbf{M}+\mathrm{F}=$ Metribuzin+Fluazifop-P-butyl

The efficiency of weed control treatments on grassy weeds can be arranged in descending order as follows, Metribuzin + fluazifop-P-butyl, pendimethalin, hand hoeing twice and oxadiarrgyl with efficiency of 95.8, 94.9, 94.5 and $93.7 \%$ and $94.9,93.6,93.1$ and $93.0 \%$ in the first and second seasons, respectively. Weed control treatments exerted a significantly reduction in fresh weight of broad-leaved weeds than the control treatment. Generally, hand hoeing twice, followed with pendimethalin, oxadiargyl and Metribuzin + fluazifop-P-butyl were the potent treatments in this respect and decreased total broad leaved weeds than the control treatments by 96.4, 95.8, 94.6 and $94.3 \%$ and $95.4,94.6,94.2$ and $93.8 \%$ in both tested seasons, respectively.

\section{Effect of weed control treatments on growth characters of onion plants:} Plant height:-

Data presented in Table 4 showed that, the onion plant height at 90 days from transplanting was significantly affected by weed control treatments in both tested seasons. All tested herbicides increased the tall of onion plant in both seasons as compared to the control treatment.

Data revealed also that the tallest plants were obtained by hand hoeing twice followed by Pendimethalin, oaxdiargyl and Metribuzin + fluazifop-Pbutyl compared to the control. The previous excision treatments increased onion plants height, respectively by $31.1,26.9,23.6$ and $19.1 \%$ in the first season and by 33.6, 29.5, 26.2 and $19.4 \%$ in the second season, respectively. 


\section{Fresh weight of leaves/plant $(\mathbf{g})$ :}

Data in Table 4 revealed that fresh weight of leaves per plant increased in weed control treatments than control treatment during both tested seasons. Hand hoeing twice gave the highest values and followed by pendimethalin, oxadiargyl and metribuzin + luaxifop-P-butyl, respectively compared to control treatment.

The superiority of hand hoeing and herbicidal treatments in this respect might be attributed to that onion plants exposed to low weed competition as a result of eliminating weeds and its negative impacts on growth of crop plant. Similar results were reported by Ved-Prakash et al. (2000) and Ghalwash et al. (2008).

Fresh weight of bulb $(\mathrm{g})$ :

Data illustrated in Table (4) showed that highest fresh weight of bulb (g), values were obtained from the application of hand hoeing twice followed by pendimethalin, oxadiargyl and Metribuzin + fluaxifop-P-butyl. Aforementioned superior treatments increased fresh weight of bulb than control treatment by $66.0,63.2,59.8$ and $52.6 \%$ and $57.3,52.6,47.5$ and $42.9 \%$ in both tested seasons, respectively. Chemical and mechanical weed control treatments reduced weed competition and thus afforded more efficient utilization of available resources to onion plants to produce taller plants having more fresh weight of leaves/plant and fresh weight of bulb than control plants. These results are coincided with those reported by El-Akhal (2004) and Ghalwash et al. (2008).

Table 4: Effect of weed control treatments on some growth characters of onion plants After $\mathbf{9 0}$ days from transplanting in both two sowing seasons.

\begin{tabular}{|c|c|c|c|c|c|c|c|}
\hline \multirow[b]{2}{*}{ Treatments } & \multirow[b]{2}{*}{$\begin{array}{c}\text { Rate/ } \\
\text { fed } \\
\text { (g or I) }\end{array}$} & \multicolumn{3}{|c|}{ First season } & \multicolumn{3}{|c|}{ Second season } \\
\hline & & $\begin{array}{c}\text { Plant } \\
\text { height } \\
(\mathbf{c m})\end{array}$ & $\begin{array}{c}\text { Fresh } \\
\text { weight of } \\
\text { Leaves } \\
\text { plant }^{-}(\mathrm{g})\end{array}$ & $\begin{array}{l}\text { Fresh } \\
\text { weight } \\
\text { of bulb } \\
\text { (g) }\end{array}$ & $\begin{array}{c}\text { Plant } \\
\text { height } \\
\text { (cm) }\end{array}$ & $\begin{array}{c}\text { Fresh } \\
\text { weight of } \\
\text { Leaves } \\
\text { plant (g) }\end{array}$ & $\begin{array}{l}\text { Fresh } \\
\text { weight } \\
\text { of } \\
\text { bulb (g) }\end{array}$ \\
\hline Pendimethalin & 1.7 & 71.4 & 40.1 & 62.2 & 69.9 & 38.9 & 57.4 \\
\hline Oxadiargyl & & 68.3 & 36.4 & 56.9 & 66.8 & 35.8 & 51.8 \\
\hline$M+F^{*}$ & $0.07+0.5$ & 64.5 & 31.8 & 48.3 & 61.2 & 29.2 & 47.6 \\
\hline Hand hoeing & Twice & 75.8 & 46.5 & 67.4 & 74.2 & 24.6 & 63.7 \\
\hline Control & & 52.8 & 16.7 & 22.9 & 49.2 & 16.2 & 27.2 \\
\hline LSD at $5 \%$ & & 3.04 & 6.32 & 9.36 & 2.36 & 7.26 & 9.89 \\
\hline
\end{tabular}

${ }^{*} \mathrm{M}+\mathrm{F}=$ Metribuzin+Fluazifop-P-butyl

Effect of weed control treatments on onion yield and its components; Fresh weight of onion bulbs $\left(\mathrm{kg} / \mathrm{m}^{2}\right)$ :

Data presented in Table 5 showed significant impact of weed control treatments on fresh weight of marketable onion bulb $\left(\mathrm{kgm}^{-2}\right)$, where, all herbicidal treatments and hand hoeing were superior in increasing these traits than control treatment in both tested seasons. On the other hand, all herbicide treatments decreased fresh weight of unmarketable onion bulb $(\mathrm{kg}$ $\mathrm{m}^{-2}$ ) in the two seasons as compared to control treatment. Results also, showed that using the tested herbicidal treatments was necessary to eliminate annual weeds and to avoid their negative impacts on onion plants. 


\section{Average bulb weight (g):}

Data revealed that average bulb weight of onion (g) was significantly affected by weed control treatments during the two growing seasons. Results denoted that weed control treatments increased marketable bulb weight $(\mathrm{g})$, but it decreased unmarketable bulb weight $(\mathrm{g})$ compared to control treatment. This might be attributed to that onion plants in the latter treatment exposed to severe competition from weeds.

\section{Marketable onion yield (ton/fed):}

Regarding the effect of weed control treatments on marketable bulb yield, data denoted that hand hoeing twice gave the highest onion yield (8.2 and 10.0 ton /fed) with 5.3 and 5.6 ton/ fed increase than control treatment, followed by pendimethalin, oxadiargyl and Metribuzin + fluazifop-P-butyl with marketable onion yield increase by $4.7,4.4$ and 4.1 ton/fed, respectively in the first season and 4.2, 3.9 and 3.5 ton/fed, respectively in the second season. Also, the results indicated that, the influence of such treatments on marketable onion bulb yield had the same trend that of plant height, fresh weight of leaves/plant, fresh weight of bulb $(\mathrm{g})$ and fresh weight of onion $(\mathrm{kg} /$ $\mathrm{m}^{2}$ ). The superiority of herbicide treatments and hand hoeing twice, might be attributed to that onion plants exposed to low weed competition as a result of eliminating weeds and its negative impacts on onion plants. Weed compete with onion plants for water, light and nutrients and the feasibility of maintaining high yield with marketable quality in absence of effective weed control is strongly doubtful. The above results are in agreement with those obtained by El-Akhal (2004) and Ghalwash et al. (2008).

Table 5: Effect of weed control treatments on onion yield during the two sowing seasons.

\begin{tabular}{|c|c|c|c|c|c|c|c|}
\hline \multirow[b]{2}{*}{$\begin{array}{l}\text { Weed control } \\
\text { treatments }\end{array}$} & \multirow[b]{2}{*}{$\begin{array}{c}\text { Rate/fed } \\
\text { (g or I) }\end{array}$} & \multicolumn{2}{|c|}{$\begin{array}{c}\text { Fresh weight of } \\
\text { onion bulb }\left(\mathbf{k g ~ m}^{-2}\right)\end{array}$} & \multicolumn{2}{|c|}{$\begin{array}{c}\text { Average bulb } \\
\text { weight }(\mathrm{g})\end{array}$} & \multirow[b]{2}{*}{$\begin{array}{c}\text { Marketable } \\
\text { yield } \\
\text { (ton/fed) }\end{array}$} & \multirow[b]{2}{*}{$\begin{array}{c}\text { Yield } \\
\text { increases } \\
\text { than } \\
\text { control } \\
\text { (ton/fed) }\end{array}$} \\
\hline & & 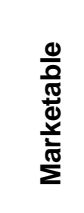 & 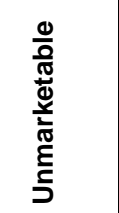 & $\begin{array}{l}\frac{0}{0} \\
\frac{\pi}{0} \\
\frac{\pi}{20} \\
\frac{10}{\Sigma}\end{array}$ & 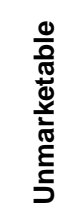 & & \\
\hline \multicolumn{8}{|c|}{ First season } \\
\hline Pendimethalin & 1.7 & 1.73 & 0.4 & 130.1 & 69.7 & 18.30 & 11.30 \\
\hline Oxadiargyl & 0.2 & 1.76 & 0.2 & 30.1 & 65.2 & 17.59 & 10.59 \\
\hline $\mathrm{M}+\mathrm{F}^{*}$ & $0.07+0.5$ & 1.68 & 0.3 & 110.9 & 70.5 & 16.80 & 9.80 \\
\hline Hand hoeing & Twice & 2.00 & 0.2 & 140.1 & 60.3 & 19.52 & 12.51 \\
\hline Control & & 0.70 & 0.6 & 70.3 & 45.2 & 7.00 & 0.0 \\
\hline LSD at $5 \%$ & & 0.41 & 0.14 & 38.55 & 20.40 & 2.05 & - \\
\hline \multicolumn{8}{|c|}{ Second season } \\
\hline Pendimethalin & 1.7 & 1.81 & 0.4 & 138.4 & 70.9 & 18.08 & 10.09 \\
\hline Oxadiargyl & 0.2 & 1.73 & 0.3 & 132.3 & 74.1 & 17.30 & 9.30 \\
\hline $\mathrm{M}+\mathrm{F}^{*}$ & $0.07+0.5$ & 1.64 & 0.4 & 138.4 & 80.4 & 16.39 & 8.40 \\
\hline Hand hoeing & Twice & 1.96 & 0.3 & 145.2 & 68.2 & 21.25 & 13.25 \\
\hline Control & & 0.8 & 0.4 & 84.7 & 40.9 & 7.99 & 0.00 \\
\hline LSD at $5 \%$ & & 0.41 & 0.14 & 39.60 & 21.90 & 2.25 & - \\
\hline
\end{tabular}

${ }^{*} \mathrm{M}+\mathrm{F}=$ Metribuzin+Fluazifop-P-butyl 


\section{REFERENCES}

Abd El-Aal, S.A. andM.S. El-Haroun ( 1989). Efficiency of some herbicides on weed control and yield of onion (Allium cepa, L.). Egypt. J. Agron.

Angira, N.N.;S.D. Singh and C.M. Singh ( 1988). Allelopathic effects of some weeds on germination growth of chickpea. Ind. J. Weed Sci. 20: 85-87.

Amrutkar, S.D.; B.M. Patil, A.P.Karunakar andD.J. Jiotode ( 2002). Effect of various herbicides on yield and uptake of nutrients in onion (Allium cepa L.). Res. Crops 3: 659-661.

Ashton, F.M. and T,J.Monaco (1991). Weed Science: Principles and Practices, 3rd Edition. Wiley, New York.

Babiker, A.G.T. and M.K. Ahmed (1986). Chemical weed control in transplanted onion (Allium cepa L.) in the Sudan Gezira. Weed Res.26: 133-137.

Bond, W. and S. Burston ( 1996). Timing of removal of weeds from drilled salad onions to prevent crop losses. Crop Prot. 15: 205-211.

Carlson, H.L. and D. Kirby ( 2005). Effect of Herbicide Rate and Application Timing on Weed Control in Dehydrated Onions. Intermountain Research and Extension Center, Univ. of California, Tule Lake, CA. Res. Progress No. 115. [Cited 5 February 2006.] Available from URL: http://danrrec.ucdavis.edu/intermountain 115_weed_control_in_onions.pdf.

Corchoranl, M.R.; T.A. Geissman and B.O. Phinney (1972). Tannins as gibberelian antagonists. Plant Physiol. (Lancaster) 49: P323-330.

Corgan, J.; M.Wall, C. Cramer, T. Sammis, B. Lewis and I. Schroeder (2000). Bulb Onion Culture and Management. College of Agric. and Home Economics, New Mexico State Univ., Las Cruces, NM. Circular 563. [Cited 5 February 2006.] Available from URL: http:// www. cahe. nmsu. edu/pubs/_circular/ Circ 563. html.

Dedonder,A. and C.F. Van Sumere (1971). The effect of phenolics and related compounds on growth and the respiration of (Chlorella vulgaris, Z). Pflanzenphysiol. 65: $70-80$.

Dryden, R.D. and C. Krishnamurthy (1974). Year round tillage. Indian J. Weed Sci. 9: 14-18.

Dunan C.M., P. Westra, F. Moore and P. Chapman (1996). Modeling the effect of duration of weed competition, weed density and weed competitiveness on seeded, irrigated onion. Weed Res. 36,259-269.

Duncan, D.B. ( 1955). Multiple range and multiple F tests. Biometrics ,11: 142

El-Akhal. I.E.M. (2004). Effect of environmental conditions and weed control treatments on onion crop. Ph.D. Thesis, Fac. of Agric., Cairo Univ.

El-Habbasha, K.M. and A.G. Behairy (1977). Influence of root exudates on seed germination and seedling development of some cultivated plants. Z. Acker-und Pflanzenbau. J. Agron. and Crop Sci. 145: 66-74.

FAO (2004). Production Year Book 2004. Food and Agriculture Organization of the United Nations, Rome. 
Gaskell, M.; X.N. Cantwell, R.Smith, B. Faber and R. Voss ( 1998). Effect of Transplant Date and Transplant Size on Production, Quality and Pungency of Sweet Onions. Newsletter Articles, Small Farms and Specialty Crops. [Cited 5 February 2006.] Available from URL: http://www.sbceo.k12.ca.us/-uccesb/sf12.htm.

Gazdag- M.Torma ( 1997). Competition between weeds and onions grown from seed bulbs. Novenyvedelem 33, 57-61.

Ghaffoor, A. (2004). Integrated weed management in different varieties of onion (Allium cepa L.). Pak. J. Weed Sci. Res. 10: 55-62.

Ghalwash, A.M.; I.E. Soliman and Azza E. Khaffagy .( 2008). Effect of some weed control treatments on transplanted onion (Allium cepa, L.) yield and its associated weeds. J. Agric. Sci. Mansoura Univ. 33: 941-952.

Glass, A.D.M. (1974). Infuence of phenolic acids upon ion uptake. III. Inhibition of potassium absorption. J. Exp. Bot. 2: 1104-1113.

Holm, L,; D. Pluncknett, J.Pancho and H. Herberger ( 1977). World's Worst Weeds: Distribution and Biology. Univ. of Hawaii Press, Honolulu.

Karim, S.M.R.; T.M.T. Iqbal and N. Islam (1998). Relative yields of crops and crop losses due to weed competition in Bangladesh. Pakistan J. Sci Ind. Res. 41: 318-324.

Mallik, M.A.B.; R.Puchala and F.A. Grosz ( 1994). A growth inhibitory factor from lambsquarters (Chenopodium album). J. Chem. Ecol. 20: 957967.

Masiunas, J.B. (2002). Weed control for commercial vegetable crops. In: Illinois Agricultural Pest Management Hand Book (ed. by Weinzierl R.A.).Dep. of Natural Resources and Environmental Sci., Univ. of Illinois, Urbana-Champaign, IL, 183-210.

Moursi, M.A.; A.A. Abd El-Gawad, A.A. El-Tabbakh, N.A. Ashoub and A.Z.Abd El-Halim (1983). Influence of sorgho and cowpea seed-root exudates on their germination and seedling development. Proc. of the $1^{\text {st }}$ Conf. of Agron. 2: 199-210.

Noll, C.L. (1978). Chemical weeding of seeded onions grown in mineral soil. In: Proceedings of the Northeastern Weed Sci. Society, vol. 32. Department of Horticulture, Pennsylvania State Univ., USA, pp. 138140.

Pandey, U.B.; D.K. Singh, J.B. Singh, J.P.N. Pandey and K.P.S. Chauhan (1991). Studies on weed control in onion. Newsletter-Assoc. Agric.Develop. Found. 11: 2-3.

Qasem. J.R. (1987). Fat-hen (Chenopodium album L.) and groundsel (Senecio vulgaris L.) interference with certain vegetable crops, with special reference to nutrition. PhD thesis. Univ. of London, London.

Qasem, J.R. (2005). Chemical control of weeds in onion (Allium cepa L.). J.Hortic. Sci. Biotechnol. 80: 721-72.

Rapparini, G. (1994). The development of mechanical methods and chemical products in the control of infestations. Inf. Agrar. 50: 111-112.

Rice, E.L. (1974). Allelopathy, Academic Press. Inc., New York, N.Y. (C.F. Rice, E.L. 1979, Allelopathy-An Update. The Bot. Review. 45:15-107). 
Sanjeev, A., K.S. Sandhu, and S. Ahuja (2003). Weed management through the use of herbicides in cabbage-onion relay cropping system. Ann. Biol. 19, 27-30.

Singh, B.; A.K. Uniyal, B.P. Bhatt and S. Prasad (2006). Effect of agroforestry tree spp. on crops. Allelopathy J. 18: 355-362.

Singh, S.P.; U.P. Pal and K. Luka (1989). Allelopathic effects of three serious weeds of Nigerian Savanna on germination and seedling vigour oif soybean and maize. J. Agron. Crop. Sci. 1672: 236-240.

Snedecor, G. W. and W. G. Cochran (1980). Statistical method $6^{\text {th }}$ Ed., lowa State Univ., Press., Ames., USA: 325 - 330.

Todaria, N.P.; B. Singh and C.S. Dhanai ( 2005). Alleopathic effects of tree extract, on germnation and seedling growth of field crops. Allelopathy, J. 15: 285-294.

Vanhala P. and K.T. Tiilikkala (1999). Effects of physical weed control on carrot and onion quality. In: Hagg M., Ahvenainen R., Evers A.M., Tiilikkala K.T., eds. Agri-Food Quality II: Quality Management of Fruits and Vegetables - from Field to Table (Turku, Finland, 22-25 April 1998). Plant Production Res., Turku, Finland, 218-221.

Ved-Prakash, A.K.; R.D. Pandey, V.P. Singh and V. Prakash (2000). Integrated weed management in winter onion (Allium cepa L.) under mid-hill conditions of north western Himalayas. Indian J. of Agron. 45: 816-821.

Wicks, G.A.; D.N. Johnston, D.S. Nuland and E.J. Kinbacher (1973). Competition between annual weeds and sweet Spanish onions. Weed Sci. 21: 436-439.

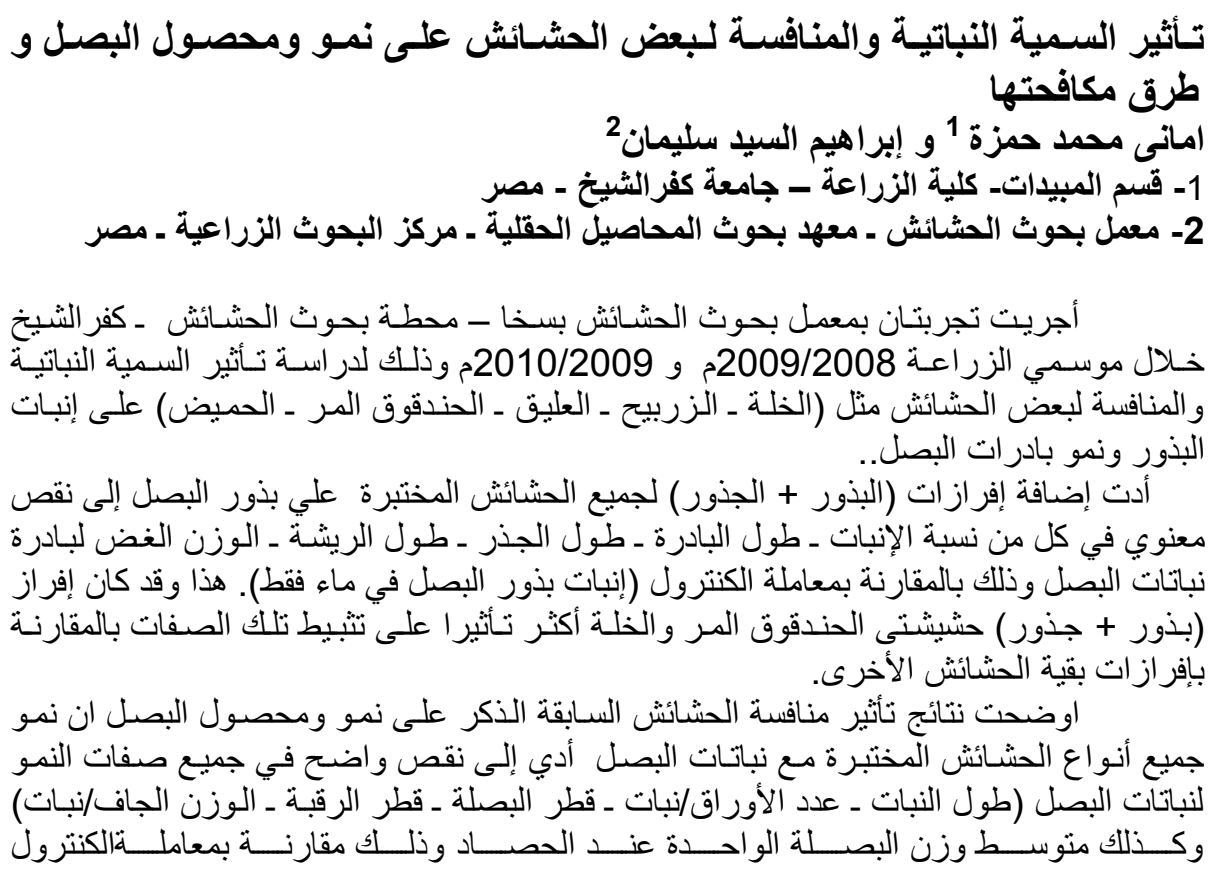


Hamza, Amany M. and I. E. Soliman

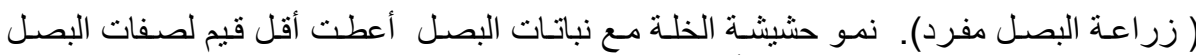
المدروسة وذلك بالمقارنة بالحشائش الأخرى.

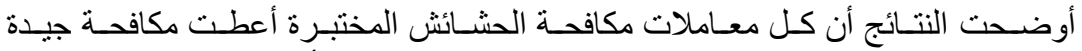

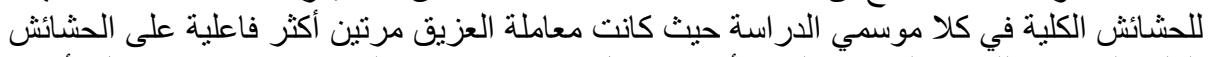

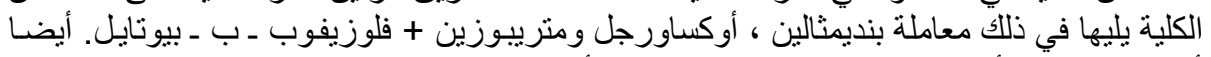

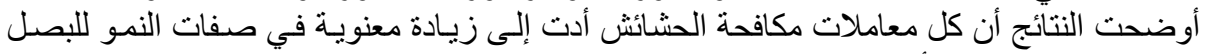

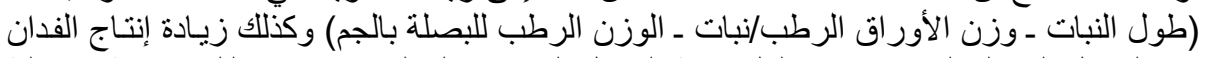

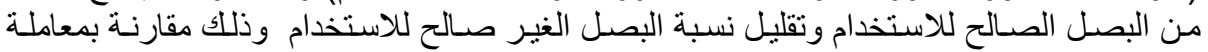
الكنترول في كلا موسمي الدراسة.

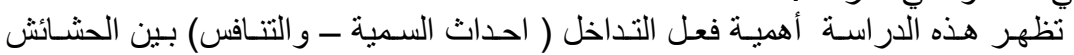

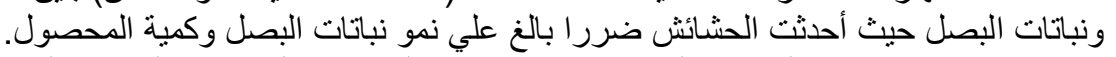

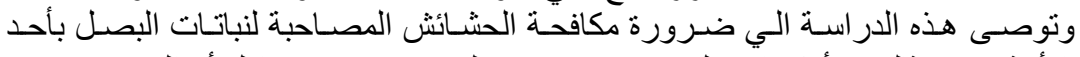

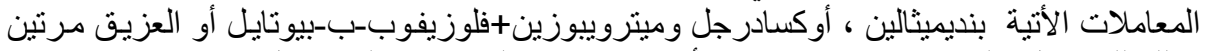

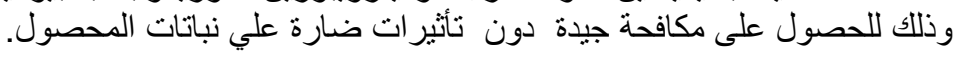

كلية الزراعة - جامعة المنصورة

كلية الزراعة - جامعة كفر الثيخ

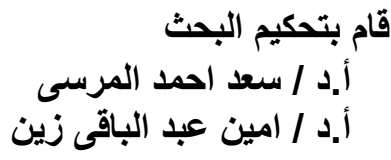

